\title{
Téoros
}

Revue de recherche en tourisme

\section{Seeing with New Eyes}

\section{Judith M. Labelle}

Volume 18, numéro 1, printemps 1999

Les jardins du tourisme

URI : https://id.erudit.org/iderudit/1072298ar

DOI : https://doi.org/10.7202/1072298ar

Aller au sommaire du numéro

\section{Éditeur(s)}

Université du Québec à Montréal

\section{ISSN}

0712-8657 (imprimé)

1923-2705 (numérique)

Découvrir la revue

\section{Citer cet article}

Labelle, J. M. (1999). Seeing with New Eyes. Téoros, 18(1), 32-38. https://doi.org/10.7202/1072298ar d'utilisation que vous pouvez consulter en ligne.

https://apropos.erudit.org/fr/usagers/politique-dutilisation/ 


\section{W A L Y I}

\section{Seeing with New Eyes}

\section{"THE REAL VOYAGE OF DISCOVERY CONSISTS NOT IN SEEKING NEW LANDS BUT SEEING WITH NEW EYES.}

\section{Judith M. Labelle}

Few communities have the capacity to formulate and execute policy that effectively integrates development and conservation. A fundamental problem is that people in many communities see development and conservation as mutually exclusive. This belief often causes residents to divide into "pro-growth" and "anti-growth" camps-a no-win approach that corrodes the decision-making process, the quality of the decisions made, and ultimately the character of the community.

Debate often focuses on "hard" data regarding the short-term financial interests of developers, a proposal's immediate contribution to local jobs and tax revenues, or the narrow technical criteria used by environmental specialists. People whose primary concern is the long-term welfare of the community feel shut out. The process simply does not respect their concern for issues perceived to be "softer" such as community character. Without their involvement, the process becomes dominated by participants with a direct financial interest in maximizing growth.

In 1998, a group of people in the Charlevoix region of Quebec decided that they wanted to become involved and play a more active role in shaping the future of their community and their region. To begin this process-and to engage more of their compatriots-they requested the assistance of Glynwood Center and its Countryside Exchange program.

\section{THE COUNTRYSIDE EXCHANGE}

The Countryside Exchange brings together international teams of volunteer professionals to work with communities on their most pressing conservation and develop= ment issues. It serves as a catalyst, using a visit by a team of objective professionalsoutsiders-to bring about collaborative action and to facilitate the creation of new coalitions, the emergence of new leaders, and the identification of shared concerns. The Exchange also provides access to the new ideas, networks and information that the community will need to shape its future.

Since 1987 , there have been more than 60 Exchanges held in North America and the United Kingdom, with more than 450 professionals from England, Scotland. Wales, Canada, France, and the United States participating as team members.

Glynwood Center is the lead sponsor of the Exchange program in North America. Glynwood is dedicated to advancing the field of community stewardship. While the Exchange serves as the "field laboratory", Glynwood draws upon its national and international network to develop new services and information that respond to community needs identified through the Exchange.

Glynwood Center is situated on 225 acres in New York State's Hudson Highlands.
It includes a conference and training facility that operates in support of Exchange communities as well as professionals working with other communities around the world. The property is home to a working farm, surrounded by several thousand acres of woodlands, hills, and streams.

All communities that participate in the Exchange program become part of the broader "Glynwood family." The Center provides opportunities for community representatives to improve their leadership skills, share experiences, and discover new ideas. Its web site (www.glynwood.org) provides easy access to Exchange reports and other information. The site's chat room and bulletin board provide a forum for communities and team members to stay in touch or ask for assistance.

Originally a professional development initiative, the Exchange is now recognized as a valuable tool for community development. Glynwood staff works with each Exchange community for several months prior to the team's arrival, assisting them in establishing a local organizing committee (LOC) and preparing for the team's visit. To be effective the LOC nust represent a diverse cross-section of community interests. It is responsible for identifying and refining community issues, developing the itinerary, and arranging logistics for the Exchange week. The LOC also spearheads implementation activities after the Exchange week.

The team's short visit is very productive due to the preparatory work of the LOC. New coalitions are created and existing partnerships strengthened. This solid foundation later allows the community to move 


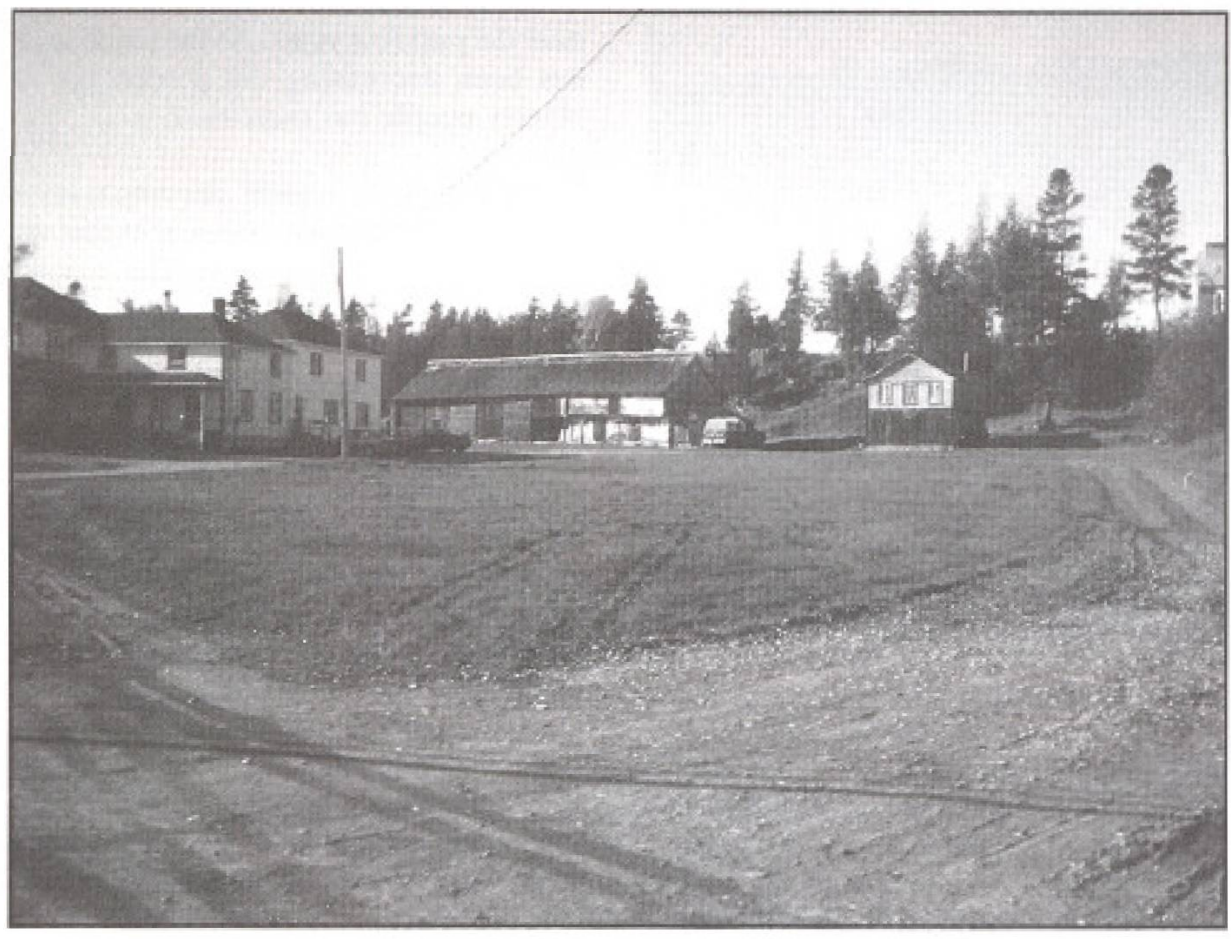

forward and implement team recommendations.

Teams are interdisciplinary as well as international. They include professionals with backgrounds in such diverse areas as economic development, science, planning, cultural resource protection, agriculture, park and countryside management, and law. This benefits both the communities and team members. By including a variety of professionals on each team, learning occurs not only across borders, but also across disciplines.

The involvement of regional partners has been a key element of the program's development. Glynwood convenes a regional steering committee composed of government and nonprofit organizations when preparing for an Exchange that will involve more than one community. This committee works with Glynwood staff to define the goals and objectives of the study area, reviews applications from communities that wish to participate, and provides technical and financial assistance for implementation projects.

The Exchange helps regional partners develop a new perspective on the issues at the local level, allowing them to be more effective in their own work. It also enables these organizations to become more familiar' with each other's work-facilitating cooperative policy and program initiatives.
The international element holds special advantages for Exchange communities. There is no doubt that a visit by an interevent, with special benefits for the host communities. Fresh and innovative ideas from abroad provide new approaches to old problems. The excitement and prestige of an international team also builds momentum for action. Local papers often track the team's activities daily, sometimes covering community issues that would not otherwise receive attention.

Preparing for the team's visit is a powerful draw. Everyone in the community can play a role in hosting the team. During the Exchange week, residents who do not ordinarily become involved in community issues do so-owing to their contact with the team.

A team of "outsiders" can promote dialogue about difficult issues that are often avoided locally. Team members-especially thoses with strange accents-can ask challenging questions without prompting community members to be defensive or angry. Residents can be more candid.

Team members seek ideas and information from everyone, including people who had felt excluded from local affairs because of their lack of professional qualification or official position. When a prestigious international team shows that it values their national team of professionals is an unusual input, others in the community do not just listen-they start talking as well.

Team members share ideas from their own experiences and suggest new ways to address community issues. United Kingdom professionals, for example, provide many practical ideas about the economic benefits of stewardship.

The 1991 Exchange in Cape Cod, Massachusetts, is a case in point. Edward Holdaway, a rural affairs advisor from Britain, suggested that "the Cape offers more than just green tourism. There is a wealth of history here, from the past 400 years. To call it "heritage tourism" is much more appropriate." Heritage tourism has since become the mandate of Heritage Cape Cod, a new organization created as a result of the Exchange. It is also a mainstay of the Cape's economy.

An international team can also provide powerful support for stewardship efforts. Their collective assessment of the community's situation, reflecting the judgment of experienced professionals from several fields and different countries, can be extremely valuable. During the 1994 Eastern Shor'e of Virginia Exchange, the team heartily endorsed Northampton County's idea for America's first "eco-industrial park." This encouraged the County and generated the support needed to carry it forward.

Jim McGowan, the coordinator of that Exchange comments, "We use the Exchange report all the time when applying for grants. It presents the issues well and validates out ideas."

The international benefits of the Exchange often continue after the team departs. Tom Harris, Northampton County Administrator, felt that the insights of British team members were of particular value to his community. Tom has since visited the United Kingdom to learn more. During that visit, he shared information about his county's initiatives, including the "ecoindustrial park" and innovative community involvement techniques.

Tom was also asked to be a United States representative to the Earth Summit's 19 th Special Session at the United Nations in New York-an invitation that took his international sharing to new heights. 


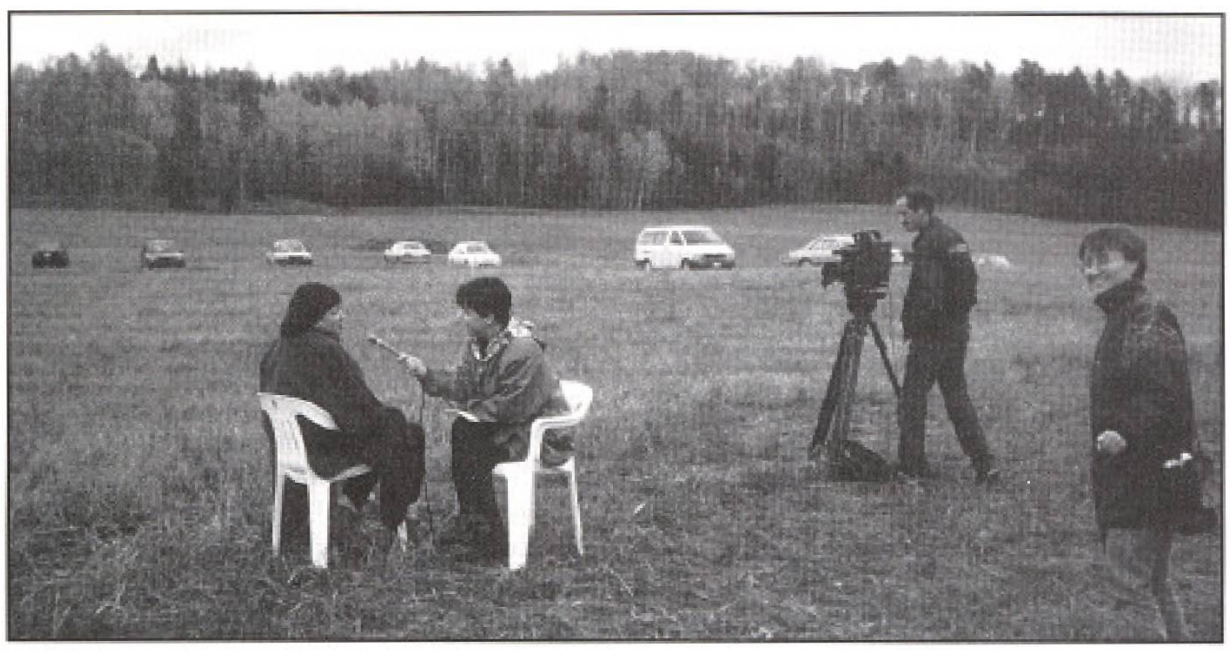

Ultimately, of course, the community reaps the benefits of this expanding international network.

The communities that have hosted a Countryside Exchange have incredibly diverse histories, landscapes, people and cultures. Not surprisingly, the results of the Exchange are just as varied.

At the conclusion of the Exchange visit, the team leaves the community with a series of observations and recommendations. Some are quite broad, other's very specific. Some can be acted upon quickly, while others require more time and a significant shift in community thinking. But the recommendations are just that-recommendations. The community must consider which to adopt, or adapt, and pursue. While the program and its regional partners can provide assistance with implementation, the community must fir'st find its own way,

Community leaders make the difference. Leadership is not always about power, politics and titles. Often it emanates from ordinary people who are simply concerned about the future of their community. Given the opportunity, these individuals can make a real difference-bringing together diverse groups and helping to stimulate collaborative action. It is not uncommon for people to become more effective leadersor to find their voices as leaders-as a result of their experience with the Exchange.

\section{THE COUNTRYSIDE EXCHANGE IN CHARLEVOIX}

During October 1998, the Charlevoix region hosted the first Countryside Exchange organized in Quebec and the first
Exchange conducted entirely in French. The theme of the Exchange was "Charlevoix in the 3 rd Millennium." The Charlevoix Community College (Centre d'études collégiales en Charlevoix) and Les États Généraux du Paysage Québécois, an association of professionals concerned with landscape preservation throughout Quebee, collaborated with Glynwood Center to organize the Exchange.

\section{THE CHARLEVOIX REGION}

The region includes some $6000 \mathrm{~km}^{2}$ of which $83.6 \%$ is occupied by forest and 150 $\mathrm{km}$ of shoreline along the St. Lawrence River. While the area includes some 20 towns and villages, the majority of the population is concentrated around two urban centers: Baie-St-Paul and La Malbaic-Pointe-au-Pic.

Charlevoix is divided into two Regional County Municipalities (RCM). The population of the RCM of Charlevoix-Est includes approximately 17,000 inhabitants while some 13,000 residents live in the RCM of Charlevoix. In the entire area, only three towns have a population greater than 3,000. Development in Charlevoix-Est was largely the result of the presence of a few important industries as well as many wealthy summer residents who were willing to invest in local services. The RCM of Charlevoix has developed largely as a result of its considerable natural resources and cultural attributes as well as the construction of important public services, including a major hospital.

The year-round population of Charlevoix has been declining gradually since 1986 , but has remained relatively stable at 31,000 over the past few years. As the population has been decreasing the percentage of elderly people has increased.

The Charlevoix region encompasses a variety of spectacular landscapes that are a major attraction for visitors. The region's exceptional character led UNESCO to designate it as a World Biosphere Reserve in 1988. The picturesque landscape has been a major draw for tourists since the 19 th century when it first began to attract wealthy summer residents. During the past 20 years, considerable effort has been made to develop tourism based on the area's unique natural and cultural resources. Nature-based tourism relies on several important features including inlets, lakes and taiga, and marine activities associated with the St. Lawrence River, the Saguenay Inlet and whale watching. Cultural tourism focuses on the Charlevoix Art Center and a number of museums and interpretation centers.

Tourism provides 2,400 jobs, more than any other sector of the economy, followed by manufacturing and forest ( 2,000 jobs), health and social services ( 1,600 jobs), and agriculture ( 1,400 jobs). However, almost $60 \%$ of the working population are employed seasonally and unemployment in Charlevoix is among the highest in Quebec.

\section{PREPARING FOR THE EXCHANGE}

Setting up a Local Organizing Committee (LOC) is the first step in the preparation of an Exchange. The LOC for the Charlevoix Exchange included representatives of the regional municipalities, museums, economic development commissions, community service organizations, the tourist association, the agricultural union, local industries, and citizens concerned with heritage conservation and economic development. The Charlevoix Community College played a key role as a focal point for organizing the Exchange. Leadership exercised by its Director, Paul-Henri Jean, and staff members Paulette Duchesne and Suzie Audet, was essential to rallying support for the project.

The first task of the LOC was to identify the major issues to be considered by the Exchange Team. That was no easy task in a region with little experience in 
community participation and where issues such as repeated zoning challenges, the demolition of historic structures, and the development of a major new casino were challenging and potentially divisive. In spite of this, the LOC members were able to work together and identify the following "big picture" issues:

\section{the need to balance economic devel- opment, community development, envirommental quality, and protec- tion of heritage and landscape:}

the need to protect the cultural and historic fabric of the community. including maditional land uses such as agriculture and forestry;

the potential for sustainable tourism development based on natural and cultural resources:

the potential for partnerships among a large number of organizations concerned with environmental protection, economic development, and tourism.

Subcommittees were set up to involve stakeholders for each of these themes. Their task was to refine issues and determine the itinerary and the activities that would give the team a quick "snapshot" of the region. The week included trips on land and water, and a series of meetings and stakeholder round tables to explore each of the issues.

In response to the issues identified by the LOC, Glynwood Center recruited the appropriate professionals who would volunteer their time to work with the community during the Exchange. In addition to representing a variety of countries and professions, the team members were all French-speaking. To help them acclimate to speaking and working together in French, the week began with a tour of the historic quarter of Quebec City. Team members included a Canadian specialist in community development and sustainable agriculture, two Regional Nature Park Directors from France, a French consultant in cultural heritage and popular festivals, a Welsh forestry consultant, a tourism and economic development specialist from Scotland, a specialist in education and interpretation from England, and the Director of the Rivers, Trails and Conservation Services of the United States National Park Service.
The team traveled by boat down the St. Lawrence River to Charlevoix where it was warmly welcomed by the community. The five days which followed were intense and tightly scheduled, enabling team members to meet with many stakeholders concerned with economic, social, and cultural issues.

The week included a visit to Île-auxCoudres to discuss the difficulties associated with development of the island-a community that can only be reached by ferry. A round-table discussion at the BaieSaint-Paul Fine Arts Center offered team members the opportunity to learn more about landscape and heritage protection issues.

Multiple use of public and private forest areas was the subject of a discussion at the Grands Jardins Park. Representatives of the Charlevoix Tourist Association piesented the proposed tourism development plan to the team. On a trip to Baie-SainteCatherine in the northeastern part of the region, the team met with citizens of this small municipality where a major marine park is being developed.

Cultural development was the subject of a meeting at the Domaine Forget Music Center and talks with community development officers enabled the team to better understand the social concerns in Charlevoix. Other round-table discussions dealt with agriculture and forestry. The team visited several farms to see agricultural opportunities and challenges.

They also met with elected officials of the two regional municipalities and with citizens in a number of public forums.

At the end of the week a crowd of 200 residents was on hand to hear the team's observations and to discuss the issues with them. The Exchange had obviously touched a chord within the community.

\section{THE TEAM"S REPORT}

The team concluded that on the verge of the third millennium, Charlevoix is an area undergoing important changes. Charlevoisiens, like residents of other regions of Quebec, increasingly question the longterm viability of traditional economic activities. With increased "globalization ${ }^{4+}$ and changes that are rapid and difficult to anticipate, Charlevoix is still in a relatively strong position. The local economy is more diversified than many rural areas and the combination of natural, social, and cultural resources offers a wide range of possibilities.

Tourism, an activity that is rapidly growing throughout the world, has been important in Charlevoix for many years.

Having a wide variety of skills enables each person to find his or her place in society. Diverse abilities permit greater flexibility-traditionally an important trait in rural areas. In Charlevoix, the diversity of economic activities al so contributes to a distinctively Charlevoisien landscape.

To build on this diversity, it is important that the region welcome newcomers who want to become part of the community and play their part in its development. These people can contribute to the dynamics of the region, which in turn will encourage young people to stay in the region rather than seek employment elsewhere.

While diversity is vital, it is also increasingly important to work toward a common vision and identity. Charlevoix must define itself elearly to attract outsiders. The area already possesses a strong sense of its natural and cultural identity. And the region has important tools, which can rally unified efforts-the most important being its status as a World Biosphere Reserve. This concept clearly emphasizes biological diversity as the basis for the distinct character of Charlevoix, including the uniqueness of its natural and cultural resources.

But how can the region use this concept, translate it into concrete actions that can become part of the daily life of its residents? It is essential to develop an integrated educational project, which all residents can contribute to and learn from-and a process through which a shared vision for the region's future can be created.

This shared vision can help unify many projects already underway : the Ecovillage of St-Siméon, the local museums, the marketing of agricultural products, and interpretative programs in natural areas. It can also provide direction for other new projects that will emerge.

Many programs and projects are in the development and planning stages. The region has a good database and the nec- 
essary organizational structures. It is time to consolidate, to recognize the progress that has already been made in a variety of sectors, and to integrate a wide range of initiatives. This is essential to improve communications among stakeholders and to work together in building a shared vision that will contribute to meeting the following objectives:

increased conirol by nesidents of Charlevoix of their territory and resources.

a unified vision and action by stakeholders throughout the World Biosphere Reserve,

the protection of the inegrity of the natural and cultural landscapes.

a reversal of the usual decisionmaking processes to provide a greater role for local initiatives.

an integration of efforts,

support for and strengthening of existing initiatives.

improved communication among stakeholders through better networking,

an economically viable and sustainable agricultural base.

multiple ase of the region's forests.

The team stressed that this is a time of change for Charlevoix. Tourism is becoming increasingly competitive and the region must establish its position quickly. At the same time, although extensive, the region's natural and cultural resources are also fragile. Therefore, exploiting them without undermining their integrity, the region's quality of life, or its tourism potential, presents a major challenge.

If the region is to shape its own future, stakeholders must work together to develop an overall vision that meets community objectives. The Exchange was an opportunity to begin this process. The widespread participation during the Exchange week was proof of the community's commitment to accept that challenge.

The team divided its report into four brond areas, each presenting a goal and series of recommandations: I-natural resources, 2-land use and economic development, 3-forestry, 4-planning and heritage protection.

\section{SUMMARY OF THE EXCHANGE TEAM'S REPORT}

\section{NATURAL RESOURCES}

The residents of Charlevoix must regain control of the stewardship of their natural resources. The region has historically exported raw materials, including forest and agricultural products. "Added value" production within Charlevolx has been limited.

The team recommended that residents become more involved in the creation of new provincial and national parks as well as decisions regarding the further development of existing parks. It was suggested that the community develop ways to maintain the existing panoramic vistas. New methods to support agriculture must be found. It was also proposed that the community explore the "multiple-use" concept of forest management including lumbering, hunting, fishing, trapping, and other forms of outdoor recreation, particularly eco-tourism. Finally, it was recommended that the community develop new partnerships with the region's universities that could provide support for natural resource management initiatives.

\section{LAND USE AND ECONOMIC DEVELOPMENT}

Agriculture contributes a great deal to the landscape, quality of life, and economy of Charlevoix. The team stressed the need to create conditions necessary to sustain agriculture.

The team made several specific recommendations. Diversification of agricultural activities and income was encouraged through the exploration of innovative forms of agriculture, including organic farming, agro-tourism, and by creating a better balance between crop production and forestry. The development of new products based on forest resources ought to be explored. Incentives such as grants and tax reductions to protect panoramic vistas were suggested. The team also recommended that the farmers in the region capitalize on name recognition by establishing a "produced in Charlevoix" label.

In terms of forestry, the team suggested that the multiple-use concept for forest resources and woodland areas would better ensure the development of economic and social potential of these areas.

\section{FORESTRY}

Team members focused on ways for the community to increase benefits from its forest resources, beginning with management: using new forestry techniques that are based on the limits of the resource, including selective cutting adapted to the specific characteristics of each site; through better use of woodland resources including diversification of products; to encouraging greater compatibility between existing commercial activities in wood= lands-forestry, fishing, and hunting. The team encouraged greater collaboration at the local level concerning management practices and initiatives to ensure that profits remain in the community.

\section{PLANNING AND HERITAGE PROTECTION}

The protection of the natural and built landscapes of Charlevoix is required if prosperity is to be achieved. The team made several recommendations related to conserving the cultural and natural landscape, primarily centered around government authority or actions on various levels. For example, it was recommended that a method be established for ensuring compatibility between regional and local plans, that governmental plans make a clear distinction between agricultural areas, urban areas, and rural non-agricultural areas, and encourage urban development within existing towns and villages. The report further suggested that development of sand and gravel pits be restricted and owners be required to rehabilitate sites that are closed. Environmental safeguards were recommended as part of planning and constructing new roads. It was also recommended that financial incentives, per= haps tax credits or grants, be provided to encourage the preservation of panoramic vistas, the elimination of undesirable 
buildings in the countryside, and to promote the renovation of existing buildings. The report proposed that construction of housing for the disadvantaged take place in the urban areas.

Moreover, the team recommended that sites and areas of heritage and cultural interest be inventoried, that owners of buildings of historical or architectural merit be encouraged through information, advice, and financial incentives to renovate them. Towns and villages should be supported in their efforts to protect heritage buildings and sites and to make them accessible to the public.

\section{TOURISM}

To ensure that tourism development contributes to landscape protection and the well-being of Charlevoix, the team proposed that new mechanisms be developed to coordinate community activities with those of stakeholders in the tourism industry. One such initiative could be the drafting of a tourism "charter" which could define the types of tourism development that will benefit the community.

Some of the specific initiatives that would reinforce Charlevoix' image as a "living and authentic natural environment" proposed by the team included:

pronoting the Marine Park and the World Biosphere Reserve designation more effectively.

promoting lourism based on visitors" discovery of the forest and marine environments, particularly through the development of bird watching.

developing new winter activities based on the traditional activities of Charlevoix residents,

developing new theme tours that would allow visitors to discover less traveled parts of Charlevoix and encourage them to extend their stay, further benefiting the local economy.

The team recommended that tourism information centers be established at all major regional access points and that alternatives to automobiles be made available. It noted that the Charlevoix Community College is a resource for the training of tourism industry employees.

\section{CULTURAL AND HERITAGE DEVELOPMENT}

The team suggested that it was necessary to bridge the gap between traditional arts and crafts and "high art", as well as between the museums and art centers and Charlevoix artists and craftspeople. It was recommended that an oral history project be undertaken to preserve oral traditions by recording senior citizens and storytellers. The creation of a major cultural activity based on an important historical event was also suggested.

\section{EDUCATION}

In order to develop educational programs that capture the keen regional interest in heritage preservation, the team had several suggestions for local education insti= tutions to consider. One was to establish a tegional strategy that include heritage preservation in educational programs from kindergarten through community college and adult programs. Another was to "twin" schools in the eastern and western parts of Charlevoix based on shared heritage concerns. It was also suggested that the role of the community college as a cultural center should be reinforced along with its ability to serve as a hub for communications among local stakeholders.

It also suggested actions that could be taken by other region nonprofit institutions such as: developing a "rediscovering my region" program that could be enjoyed on weekends and holidays; creating an annual contest for the best example of heritage protection or heritage education; that the Forget Music Center offer a program of community concerts that would also inform the community of the Center's objectives and publicize its other concerts.

The team's complete written report will be available in French in March and can be found on the web site of Les Etats Généraux du Paysage Québécois at www.paysage,qc.ca, and at www,glyn wood,org-the Glynwood Center web site. An Executive Summary will be printed in French as a local newspaper insert. It will also be available in English. As Alain Boucher, a citizen who helped organize the Exchange said: "The report must be publicized widely throughout the community. It's like sowing a garden: if the soil is good and the gardener attentive, the report's ideas and proposals will take root and grow".

\section{IMPLEMENTATION}

The morning after its public presentation, the team met with members of the LOC to discuss recommendations and implementation. In the weeks following the Exchange, the LOC created an implementation committee, chaired by the Community College. Committee members indicated that implementation must emphasize creation of links between regional agencies and members of the community.

Community health and cultural stakcholders have already indicated their willingness to develop an action plan based on that approach. The implementation committee also believes that publicizing the Exchange Team's report is a crucial step to a grassroots process that must remain democratic and based on broad support. Maintaining momentum is probably the crucial element in ensuring the ongoing impact of the Exchange.

The team's recommendations have certainly stimulated discussion within the community. The recommendations were generally well received. In some cases they have led to a questioning of current priorities and actions by local institutions and community organizations. While a few perceived some of the report's conclusions as "criticism for outsiders," most people involved saw them differently and acknowledged the spirit in which they were made.

For Claude Harvey, the new Director of the Community College, the team provided a "snapshot of reality" which is often difficult for the residents themselves to see. Denis Laliberté, an LOC member and organizer of a festival which celebrates the tradition of Quebec woodsmen or "coureurs de bois" put it this way: "The report confirmed many convictions that we already had about our development but it's important to have an outside view which may, for some people, carry more weight. The strength of the exchange lies in the fact that the information which the team obtained came not only from local officials but also from the people who live and work in the region."

Conrad Paradis, an environmental specialist with the Community Health Board 


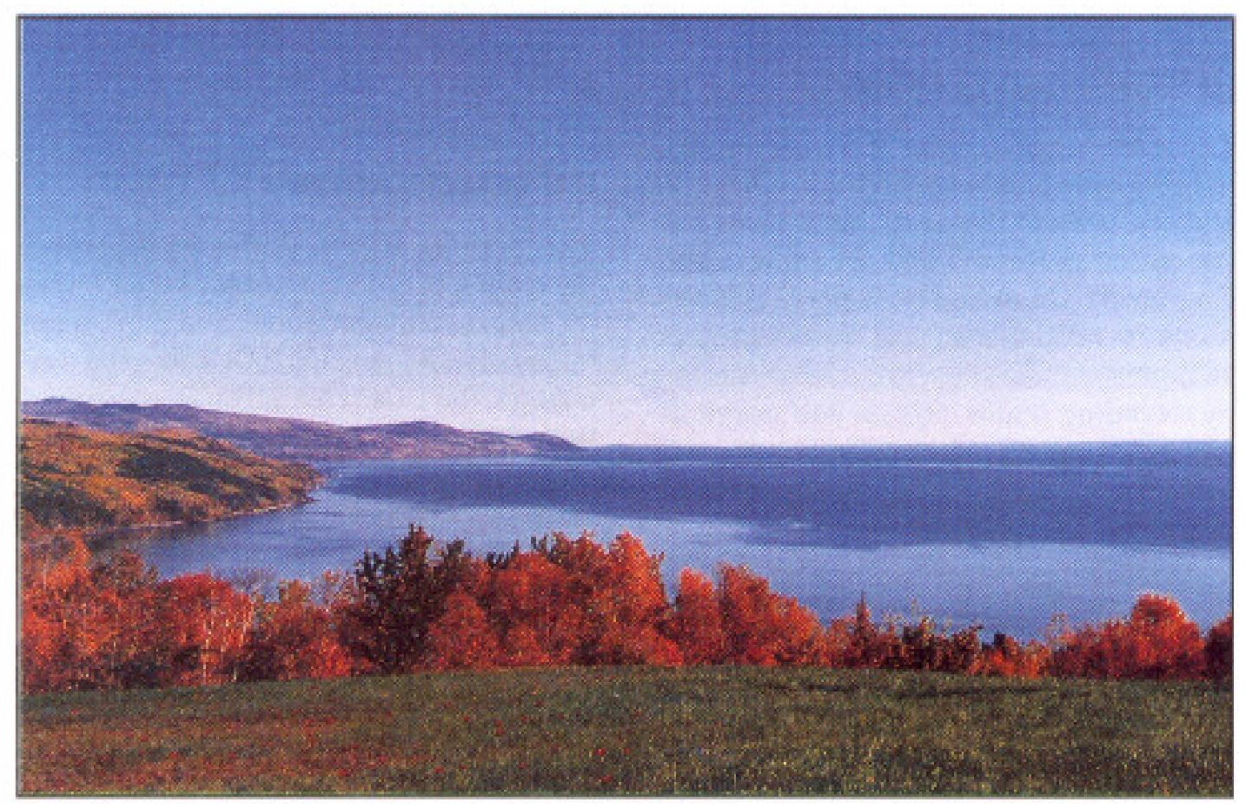

(CLSD) saw the team's visit, "not as a way to obtain all the answers, but rather as a source of expertise and experience to help the community choose the best option for balanced future development which takes into account the region's specific characteristics,"

\section{OVERALL LESSONS LEARNED THROUGH THE EXCHANGE PROGRAM}

The Exchange program is rich with lessons learned. But the key lessons-how communities can shape their future-are drawn from our experience at the local level. Many relate to decision-making processes, others to the ideas that inform those processes. A few of these lessons warrant highlighting.

\section{PUTTING THE "PUBLIC" BACK INTO PUBLIC POLICY}

Many of the recommendations contained in an Exchange report may have a familiar ring to the community-they have been proposed before in one consultant's report or another. But while these reports are gathering dust, the Exchange report serves as a call to action.

Why? Because consultants' reports are often narrow in their scope, dealing with one particular issue, isolated from the larger context. Often they are prepared by "experts" only, with little input from the community. The people who must support the implementation effort are not involved and have little interest in participating.

In contrast, the Exchange program involves the community-beginning with the preparation for the team's visit. They also take part in the discussions that lead to the team's recommendations and form the broad-based coalition needed for their implementation. Experience with the Exchange sets the stage for similar action on other public issues. As one official in Port Gibson, Mississippi, exclaimed, "Oh, I get it! You're talking about putting the "public" back into public policy."

\section{THE OPPORTUNITY PROVIDED BY THE POWER OF PLACE}

As Daniel Kemmis, former Mayor of Missoula, Montana, observed, "Places have a way of claiming people." Commitment to their "places" drives people's willingness to participate in public affairs. While there are many who want to contribute to an improved quality of life, there are few opportunities for public involvement other than land-use proposals, which are usually narrow in scope and highly contentious. Community members often feel that the fate of their community is in someone else's hands.

The widespread desire to play a role in shaping their future is evidenced by the organizing committee for each Exchange dozens of people who participate in the site. The program helps them find each other by offering an opportunity to think creatively about the community's future and to build relationships with others who are not content to let the status quo determine their future. Once these relationships are established and have resulted in a successful Exchange, they provide a solid basis for further action.

The team can also help communities begin to assess their hidden economic opportunities, natural resources, and cultural assets-part of a comprehensive knowledge base essential to effective long-term planning.

Neighboring communities within a region must take concerted action if they are to affect the application of those policies. Even so, the concept of local control is so deeply embedded in some communities that political leaders do not usually recognize that their failure to cooperate on a regional level undercuts plans for their community. The Countryside Exchange can help communities within a region recognize their shared interests and begin to explore the strength of a regional approach that also reflects and respects 10cal community plans.

\section{THE NEED TO MOVE TOWARD COMMUNITY-BASED REGIONALISM}

Even a community with a clear vision of its future and a strong, shared commitment to implementing that vision, is subject to the vagaries of state (or provincial) and national policies.

Judith M. Labelle is president of Glynwood Center

\section{AUTHOR'S NOTE}

This article draws extensively and often directly from the report prepared by the Exchange Team in the Charlevoix Exchange, as translated by Marie-Claude Robert who served as the Regional Coordinator for that Exchange and David Belgue, President of Les Elats Généraux du Paysage Quebecois, co-sponsor of the Exchange.

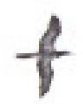

